Portland State University

PDXScholar

1973

\title{
Ernst Cassirer and the Synthesis of the Past : a Paradigm in the History of Ideas
}

Mart Stewart

Portland State University

Follow this and additional works at: https://pdxscholar.library.pdx.edu/open_access_etds

Part of the Continental Philosophy Commons, and the History Commons Let us know how access to this document benefits you.

\section{Recommended Citation}

Stewart, Mart, "Ernst Cassirer and the Synthesis of the Past : a Paradigm in the History of Ideas" (1973). Dissertations and Theses. Paper 2042.

https://doi.org/10.15760/etd.2041

This Thesis is brought to you for free and open access. It has been accepted for inclusion in Dissertations and Theses by an authorized administrator of PDXScholar. Please contact us if we can make this document more accessible: pdxscholar@pdx.edu. 
AN ABSTRACT OF THE THESIS OF Mart Stewart for the Master of Arts in History presented July 27, 1973.

Title: Ernst Cassirer and the Synthesis of the Past: A Paradigm in the History of Ideas.

APPROVED BY MEMBERS OF THE THESIS COMMITTEE:

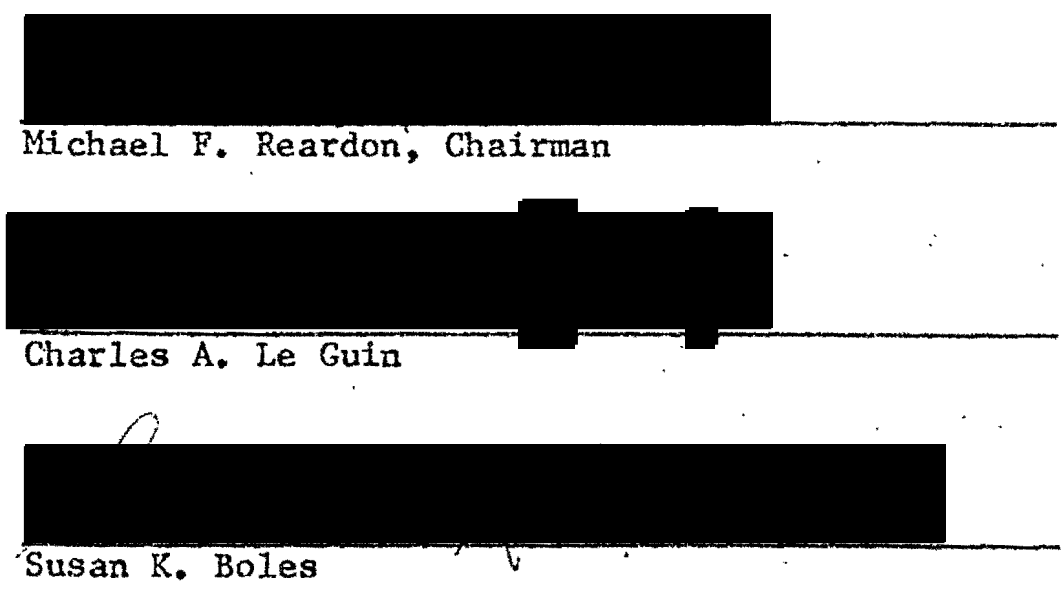

The problem of a method of historical analysis played an integral part in the scholarship of Ernst Cassirer, German philosopher and historian. An Essay on Man, the work for which he is best known in the United States, includes his most lucld discussion of the tasiks and aims of the historian. The historian must reconstruct the past, infusing it with the immediacy of a living expression. "Rebirth of the past" gives man a better view of his potentialities, a freedom to see beyond the demands, characteristics, and contingencies of the moment. This view of history and the historian's task. was reiterated 
by Cassirer in several of his works on theory and was implicit in a number of his books and articles on historical topics. The following critique will focus on Cassirer's discussion of history and on his historical method as it was demonstrated in several of his mitings. Despite the criticism of Casstrer's penchant for structure and affinity for schemata, he has had a profound influence on the general community of historians. His work in many areas was unique and he did considerable original research. He has had some influence on subsequent historians, especially with some of the specifics of his data. Even the abundance of criticisms of his works attests to the seriousness with which he has been viewed as a historian.

But Cassirer used a paradigm charged with possibilities for fallacy. He accepted the idealist view that "mind" and "matter". are.... identical, that "mind" operates according to the rules of logic, and that logic can be applied to the history of thought. He used the analytic-synthetic idealist approach, the breakdown and recreation of a body of data. The history of thought-the history of the "mind"-moved from an analytical period to an organic one in a never ending process, Cassirer believed. And at each juncture, at each organic stage, there was a transitional figure to bring everything together again: Nicholas of Cusa, Descartes, Letbniz, Kant, and others. Cassirer, in his response to the "crisis" situation, to the plethora of Eragmented theories of man, to an analytical period in European thought, saw himself as a new transitional figure. His paradigm was a response to a "crisis" in Kuhn's sense of the word. But at the same 
time, within the framework of Cassirer's scheme, it was Intended to provide the new synthesis in the development of the "modern mind." Cassirer's synthetic paradigm fulfills the criteria Hollinger names for "successful".works in the fleld. And he must be lauded for explaining his methodological position and consistently abiding by It. But if the basic tenets of idealist philosophy are not accepted, his entire model fails as a viable paradigm for historical research and writing. Implicit in the crittcisms of Price, Skinner, Foucault, and others is the recognition of the absurdity of these tenets. The pursuit of the history of the "mind," of the "knowledge of knowledge," can only lead to historical absurdities. 
ERNST CASSIRER AND THE SYNTHESIS OF THE PAST:

A PARADIGM IN THE HISTORY OF IDEAS

by

MART STEWART

A thesis submitted in partial fulfillment of the requirements for the degree of

MASTER OF ARTS

in

HISTORY

Portland State University

1973 
TO THE OFFICE OF GRADUATE STUDIES AND RESEARCH:

The members of the Committee approve the thesis of Mart Stewart presented July 27, 1973.

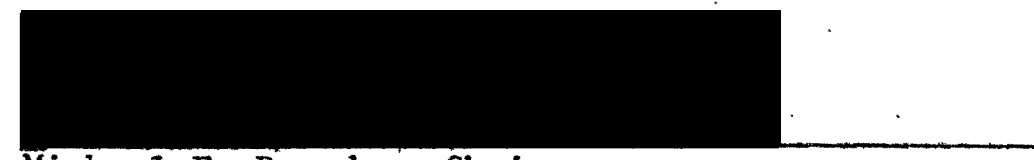

Michael F. Reardon, Chairman

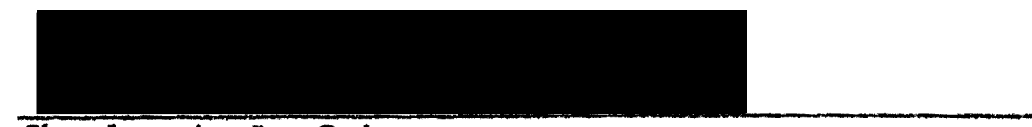

Charles A. Le Guin

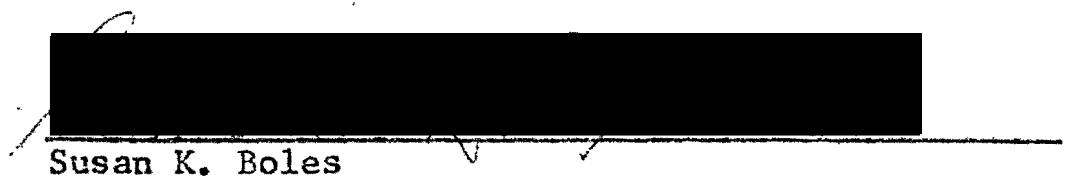

APPROVED:

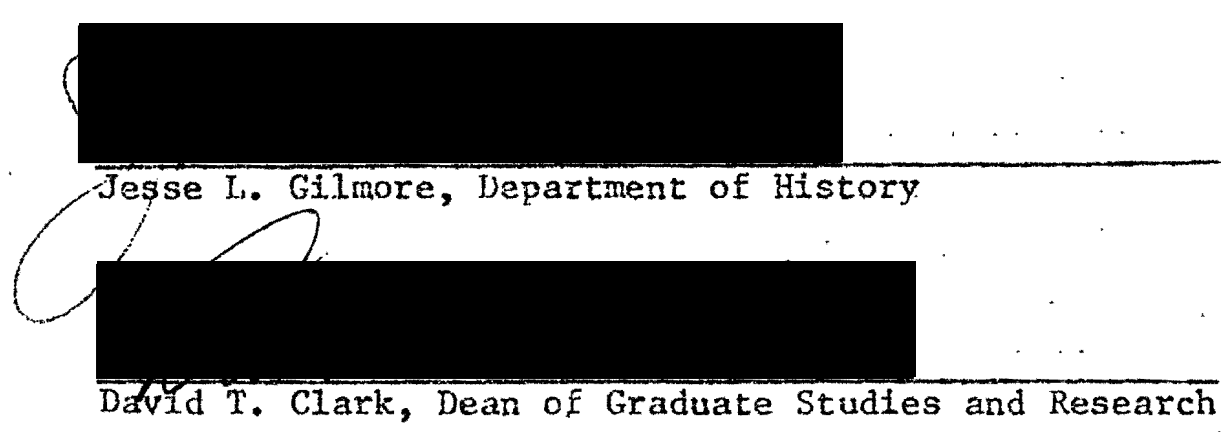

July 27,1973 
I INTRODUCTION: THE MODEL' . . . . . . . . . . 1

II THE PROFESSIONAL ACADEMICIAN:

A BIOGRAPHICAL SKETCH ............ 7

III THE "CRISIS" AND THE RESPONSE:

THE PHILOSOPHY OF SYMBOLIC FORMS. . . . . . . 14

IV SYMBOLIC RECONSTRUCTION, FUNCTION,

AND STRUCTURE: THE PARADIGM. . . . . . . 26

$\checkmark$ FUNCTION AND RAGE FOR COHERENCE:

THE PARADIGM CRITIQUED . . . . . . . . . . . 44 


\section{INTRODUCTION - THE MODEL}

The problem of a method of historical analysis played an integral

part in the scholarship of Ernst Cassirer, German philosopher and

historian. An Essay on Man, the work for which he is best known in

the United States, includes his most lucid discussion of the tasks and

aims of the historian:

The historian must learn to read and interpret his documents and monuments not only as dead remants of the past but as living messages from it, messages addressing us in a language of their own.. . It is this 'palingenesis,' this rebirth of the past, which marks and distinguishes the great historian. There is also a prophecy of the past, a revelation of its. hidden 1ife. History cannot predict the events to come; it can only interprer the past. But human life is an organism in which all elements imply and explain each other. Consequently, a new understanding of the past gives us at the same time a new prospect of the future which in turn becomes an impulse to intellectual and social iffe. For this double view of the world in prospect and retrospect the historian must select his point of departure. He cannot find it except in his time... (in) our present intellectual interests and our present moral and social needs. 1

The historian must reconstruct the past, infusing it with the irnediacy of a living expression. "Rebirth of the past" gives man a better view of his potentialities, a freedom to see beyond the demands, characteristics, and contingencies of the moment.

This view of history and the historian's task was reiterated by Cassirex in several of his works on theory and was implicit in a

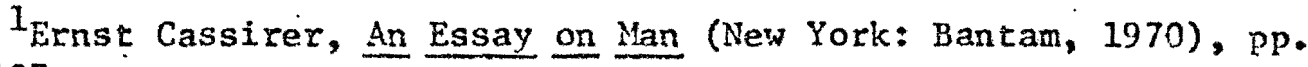
$195,197$. 
number of his books and articles on historical topics. The following critique will focus on Cassirer's discussion of history and on his historical method as it was demonstrated in several of his writings.

A few preliminary observations about the necessity for methodological commitments in historical analysis, and about the nature of these commitments should precede the critique. Every discipline has certain aims and methods which are considered indigenous to the discipline; and any historian follows a method of procedure in his analysis of the past, either implicitly or explicitly. In the lacter case, the historian may make a statement about the method used in the analysis; in the former, he may covertly adhere to the method used by the community of historians of which he is a part. In order to avoid extreme relativity or a chaos of narrative generalizations, the historian must appropriate or develop a flexible but rigorous method of interpretation and use it consistently. This methodology, in its simplest form, may follow a few general rules about the logic of analysis; or it may, at the other extreme, embody large philosophical principles about the movement of history.

There is only the most general consensus among historians about what history as a discipline is and what its procedures entail. But general communities of historians-professional historians and students who agree on basic rules for doing history--most certainly do exist, as they did during Cassirer's lifetime. Any understanding of the works of different historians must be preceded by a delineation of their respective analytical, interpretive methods. These general methodological presuppositions can be isolated both in terms of the 
commity and in terms of the individual historian.

A recent contribution to the philosophy of science has given modern scholars a conceptual framework for carrying oụt this isolation of specific methodologies. Thomas $\mathrm{S}$. Kuhn, in his Structures of Scientific Revolutions, presents the "paradigm theory," a conceptual contribution of such flexibility in application that it has been adapted and appropriated by some historians. ${ }^{2}$ Kuhn uses "paradigms" to specify certain accepted methodological exanples of ". . actual scientific practice--examples which include law, theory, application, and instrumentation together--(which) provide models from which spring coherent traditions of scientific research." 3 The operating traditions are based on their ability to organize the experiences of the specific commities. An accepted tradition gives the commulty criteria for distinguishing different activities, it sets priorities among these activities, and it gives the community a model around. which the community's common activities are arranged. These activ-' ities--the commity's experience--are contingent on the model that organizes them into a common experience. And in the process of "actual scientific practice," in the actual use of the paradigm, the comunity's experience--the specialized problems considered by the community using the paradigm--is transformed into something comprehensible and, within the confines of the specific communty, concrete. The "paradigm," then, has a social basis, and its function is one of

2Thomas S. Kuhn, The Structure of Scientific Revolutions (Chicago: University of Chicago Press, 1971).

${ }^{3}$ Ibid., p. 10. 
organization. The community is organized around the paradigm; the paradigm is therefore socially grounded.

Traditions sometimes lose their constituencies, Kuhn continues, and the comunity either accepts a new paradigm, or it dissolves, with new commities forming around new paradigms. These "paradigmatic shifts" are responses to crises situations, in which the reigning paradigms no longer provide the adequate tools to solve new problems, no longer have the common acceptance of the communities. Most of Kuhn's book is devored to discussing these shifts, the "structure of scientific revolutions."

In a recent article in the American Historical Review, David A. Hollinger discusses the application of Kuhn's theory to history as a discipline. 4 Hollinger recognizes that communities of historians with some common consensus of opinion on the aims and procedures of history do exist. They are not as well-defined as scientific cormunities; buti: their existence cannot be disputed.

Among the practitioners of the discipline of history there are, as in other disciplines, some commonly held beliefs about the nature of the discipline that in turn define the discipline. These beliefs constitute a paradigm. Hollinger lists a number of general convictions that he believes have a common acceptance among historians. In order to be deemed "successful," Hollinger contends, each work of scholarship in the field must assure tes professional readers" . . that the questions it asks are comprehensible, and worth asking; that

${ }^{4}$ David A. Hollingex, "T. S. Kuhn's Theory of Science and its Implications for History," Anerican Historical Review, Vol. 78 (1973), Pp. $370-393$. 
the sources it has examined are indeed the ones most relevant to the inquiry; that its analysis of the sources has been rational." By "rational" he means" . . that the author's presuppositions about human nature, the behavior of groups, causation, etc. are either shared by his readers or are perceived by his peers as respectable competitors to the views of the readers." 5 . There are many paradigns within this greater one, Hollinger argues, such as the Freudian, the Marxian, and other models of the same kind.

Cassirer's methodological views can also be seen as a paradigmatic model. He was to an extent influenced by the reigning paradigm in the comunity of which he was a part in his early years, the NeoKantian school at the University of Marburg. By the time he wrote his first specific work on intellectual history, his model had changed somewhat, but it was part of another community, one which his paradigm defined. I will attempt, in the following critique, to isolate Cassirer's paradigm and show how he used that paradigm in historical analysis. The "crisis" to which he responded; the communty to which he belonged, and his "philosophy of symbolic forms"--the springboard of his historical method--will be sketched. Cassirer's involvement in a cormunity. paradign will be established and will be critiqued according to commonly held rules of historical analysis and procedure:. But I intend to concentrate on Cassirer's way of doing history, on the model he used to analyze and synthesize specific historical topics, rather than on the characteristics of the paradigm's social base.

5 Ibid., p. 383 
For the purposes of this discussion, I will anly mention Cassirer's epistemological presuppositions. They were, indeed, part of his paradign, but his methodology as it applied to the historian's craft was not necessarily contingent on his epistemology. His writings on history constituted a real historical achievement in and of themselves, and have been recognized as such by both those who criticize and applaud Cassirer. Further, Cassirer intended his writings on history to be viewed as historical works, not epistemological ones.

In other vords, the "crisis" situation to which he responded, his academic training and accomplishments," and his "philosophy of symbolic forms". will be sketched only to establish the validity of. any effort to critique his model as a "paradigm" and to provide a guide to the conceptual vocabulary he used when discussing methodology. I will focus on his view of the historian's aims and procedures, and on his methodology as it was practiced in his books and essays on historical topics and developments.. I will attempt to isolate a paradigm, a methodological model, and will critique it as such. 
CHAPTER II

THE PROFESSTONAI, ACADEMTCIAN:

A BIOGRAPHICAI SKETCH

Cassirer was a perfect example of the professional academician. His long and fruitful life revolved around various academic commities, he wrote for an academic audience, and his reputation was and is an academic one. From 1892, when he first entered the University of Berlin, until his death in 1945, when he was teaching at Columbia University, he worked and lived in a close contact with academicians of different universities. All his writings, from his book on Letbniz, published in 1902, to his Myth of the State, published posthumousiy, were written for professional scholars. His work was of interest only to the academician and the student, and it remains so taday.

His early training was in both philosophy and history. He entered the University of Berlin at the age of eighteen and for two years went from one school to another, unable to find a course of study that satisfled him. In the summer of 1894 he took a course on Kant at the University of Berlin. He became interested in Kantian philosophy and those philosophers involved in its revival in German academic circles at that time. The teacher of the course on Kant, Georg Simmel, introduced Cassirer to Hermann Cohen's works on Kant. Cohen played a primary role in the initial reformulation of Kant's philosophy as it was embraced by the Marburg School of Neo- 
Kantianism. He rejectad the notion of a noumenal world, the Ding-ansich standing behind the phenomenal world. The categories of reality derive from pure thought alone, he contended, independently of sense data. Cohen developed an epistemology much more idealistic than Kant, but submitted it to the same rigorous logic. Consciousness operates according to the laws of logic, Cohen believed. And because all reality exists within consciousness, then all raality is logical. Consequently, the laws of logic become the laws of nature. A11 analysis operates according to the same standards, except that cultural and historical analysis must also deal with questions of value: The analysis of value questions also demands a rigorous logical method. Ethical norms have their foundation not in experience, but in the structure of the mind. Historical Weltanschauungen must be approached and delineated from the standpoint of absolute and universal logic and ethics.

The only reality similar to the Ding-an-sich is ideal, Conen maintained. Knowledge of an object is a progressive process. History is the endless process by which man, through the use of reason, accumulates pure knowledge of both nature and society. The objects of both the natural sciences and the cultural sciences (Kulturwissenschaften) are known perfectly only at some infinite point in time. Analysis of objects of knowledge, and synthesis of the parts analyzed--the 
knowledge of phenomena-is an "unendliche Aufgabe."

Cassirer vent to Marburg and quickly established himself as a leader among Cohen's group of students. At this time he also studied carefully the works of Plato, Descartes, and Leibniz. Mathematics and biology were two more areas of special interest to Cassirer during this period. 7 He had taken some classes from Dilthey at the University of Berlin, and he continued to increase his familiarity with Dilthey's attempts to unify the methods of the cultural sciences (Geisteswissenschaften). 8

Cassirer's doctoral dissertation dealt with Descartes' theory of knowledge, and he used it for the first section in an extensive study of Leibniz published in 1902 (Leibniz' System in seinen

${ }^{6}$ Dimitry Gawronsky, "Ernst Cassirer: His Life and His Work," in The Philosophy of Enst Cassirer, ed. Paul Schilpp (Menasha, Wisconsin: Ceorge Banta Publishing Co., 1949), P. 9. Also see Georg C. Iggers, The German Conception of History (Middleton, Connecticut, Wesleyan University Press, 1968), pp. 144-147; and Ernst Cassirer, "Herman Cohen," Social Research, Vol. 10 (1943), pp. 219-232.

${ }^{7}$ Gawronsky, pp. 6,8 .

8 There has been considerable debate over the translation of this term. The most commonly accepted translations are "cultural sctences," or "humanities." For an explanation of the concept of Geisteswissenschaften and of Dilthey's philosophy, see H. A. Hodges, The Philosophy of Wilhelm Dilthey (London: Routledge and Kegan Paul, 1952); Hajo Folborn, "Withelm Dilthey and the Critique of Historical Reason," in European Intellectual History Since Darwin and Marx, ed. W. Warren Wagar (New York: Harper and Row, 1966), pp. 56-88; Iggers, pp. 133144; For a comparison of the Neo-Kantians' Kulturwissenschaften and Dilthey's Geisteswissenschaften, see Rudolf Makkreel, "Wilhelm Dilthey and the Neo-Kantians: The Distinction of the Geisteswissenschaften and the Kulturwissenschaften," Journal of the History of Philosophy. Vol. 7 (1969), Pp. 423-440. 
wissenschaftlichen Grundlagen). 9 In 1904 and 1906 respectively he edited and published two volumes of Leibniz's writings.

While doing research on Leibniz he began working on a probiem that was later to grow into the three-volume Das Erkenntisproblem in der Philosophie und Wissenschaft der neueren Zeit $(1906,1907$, and 1920 respectively). He attempted to give a comprehensive picture of the development of epistemology in philosophy and science from the Renaissarice to the present. These three volumes were not historical works, but dealt with purely epistemological problems in their historical development. The works are of a Neo-Kantian orientation in that their focus was on philosophers and on epistemological problems of interest to the Neo-Kantian. 10 Many of the problams and thinkers he considered in these volumes were reconsidered in his later historical works, but for different reasons. His reputation as a scholar was established with the publication of the first two volumes. 11

Cassirer continued to write and publish," and in $1910 \mathrm{his}$ Substanzbegriff und Funktionsbegriff appeared. It was devoted to the problem of concepts, the logic of concepts, and the process and function of conceptual knowledge. 12 Substance and Function; as the work appeared in English, gave Cassirer an International reputation. It

${ }^{9}$ Cf. R. Klibansky and W. Solmitz, "Bibllography of Ernst Cassirer's Writings," Philosophy and History: Essays Presented to Ernst Cassirer, eds. Raymond Klibansky and H. J. Paton (New York: Harper and Row, 1963), pp. 338-353.

${ }^{10}$ Gawronsky, p. 9.

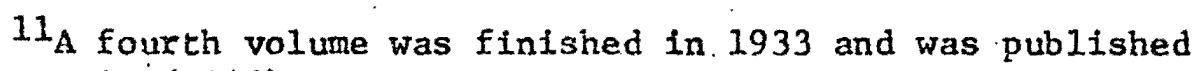
posthumously (1946).

12Gawronsky, p. 18. 
was translated into a number of foreign languages. This work also led to Cassirer's split with Cohen over some of the specifics of the concept theory. 13

In the next decade Cassirer wrote a number of epistemological essays and edited several of Kant's and Leibniz's vritings. The work upon which his reputation as a philosopher is based was pub1ished in 1923, volume one of Philosophie der Symbolischen Formen (Die Sprache). A second volume followed in 1925 (Das mythische Denken), and a third in 1929 (Phänomenologie der Exkenntnis). Cassirex's interests continued to revolve around problems relevant to the leo-Kantian academic comunity, but the scope of his analyses was considerably broadened. The "philosophy of symbolic forms" represented a unique contribution on his part, and its aim represented the broadenad scope of his interests and analyses. $\therefore$ In these volumes he defined culture as the sum total of man's "work.". Man's "work," in turn, is a product of an endless series of cognitive, symboltc activities. The three-volume Philosophy of Symbolic Forms purported to analyze the structure of these activities, focusing on special categories of "symbolic forms" underlying different realms of human activity: religion, art, langüage, myth, and science.

By this time Cassirer had gone beyond the Neo-Kantianism of his Marburg period, and had created an epistemology of considerable originality. ${ }^{14} \mathrm{His}$ concern for the historical genesis of cultural

\section{Ibid., p. 21 .}

$14 \mathrm{Cf}$. William H. Werkmeister, "Cassirer's Advance Beyond NeoKantianism," in The Philosophy of Ernst Cassirer, ed. Paul Schilpp, pp. 757-798. 
forms is documented by the framework he used for the examination and presentation of the "philosophy of symbolic forms." This philosophy, as will be shown later, necessitated a historical perspective. And his research into problems of the history of philosophy and the history of ideas bore fruit in a number of historical monographs and essays written and published during this period. Individuum und Kosmos In der Philosophie der Renaissance appeared in 1927... In 1932 Die: Platonische Renaissance in England und die Schule von Cambridge, Die Philosophie der Aufklärung, and Das Problem J.J. Rousseaus followed. Cassirer, a Jew, did not wait to be dismissed from his post as rector of the University of Hamburg. When Hirler became Chancellor in 1933. He left Germany, going to Oxford, where he lectured for two years. In September, '1935, he went to Goeteborg, Siveden, and remainad there for six years. In 1941 he accepted an invitation from Yale University and came to the United States as a visiting professor. He had originally intended to remain for two years only and then return to Sweden, but the entrance of the United States into the War changed his plans. He continued teaching at Yale until the sumer of 1944 , when he accepted an invitation to teach at Columbia Universizy. While Cassirer was in the United: Stares he wrote a number of articles of some historical import, including "Giovanni Pico della. Mirandola" (1942), "Galileo: A New Science and a New Spirit" (1942), "Some Remarks on the Originality of the Renaissance" (1943), "The Place of Vesalius in the Culture of the Renaissance" (1943), "Newton and Leibniz" (1943), Rousseau, Kant, Goethe (published posthumous1y, 1946), and "Galileo's Platonism" (published posthrmously, 1946). He 
continued writing on epistemological problems during this time, but his orientation shifted more towards analysis of culture and the state. 15 Both Zur Logik der Kulturwissenschaften (1942) and An Essay on Man, the work for which Cassirer is probably best known in American academic circles, ras published just a few months before his death on Apri1 13, 1945.

15 F. S. C. Northrop, "Obituary: Ernst Cassirer," The Phtlosophical Review, Vol. 55 (1946), p. 451. 
CHAPTER III

THE "CRISIS" AND THE RESPONSE: THE PGILOSOPHY

OF SYSBOLIC FORMS

A 'philosophy of symbolic forms' can make good the claim of unity and universalicy, which metaphysics in its dogmatic form must abandon. Not only can it unite these various modes and directions of our knowledge of the world; over and above, this, it is capable of evaluating every attempe at understanding the world, every analysis of it which the human is capable or, and conceiving each in its true character. It is in this manner that the problem of objectivity first becomes visible in fits full scope; and taken in this sense it encompasses not only the cosmos of nature but also that of culture. 16

Cassirer made the above clain for his "philosophy of symbolic forms" in a number of his writings. It provides the "clue of Ariadne," he believed, leading out of the "labyrinth" of modern philosophy. 17 Like many of his contemporaries, Cassirer felt there to be a "crisis" in European philosophy, that a plethora of theories with 1itele comon ground made the "modem theory: of man" a collection of fragments. This "theory" had Iost its, intellectual "center," Cassirer contended, and "Each theory becomes a Procrustian bed on which the empirical facts are stretched to fit a preconceived pattern." 18 . While he did. not divell on the nature of the "crisis" situation, he saw it as a pervasive problem in his era. And his recognition of this situation

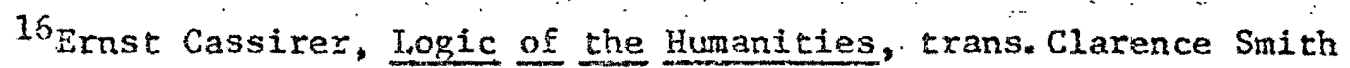
Howe (New Haven: Yale University Press, 1963), p. 67.

${ }^{17}$ An Essay on Man, p. 24 .

18. Ibid., p. 23. 
served as a departure point and justification, he believed, for his "philosophy of symbolic forms."

Cassirer was not alone in recognizing a "crisis" situation in. European culture at that time. Some of the labels used by historians to characterize the period--"cultural despair,"19 "dissolving certainties,"2n "the revolt against positivism"2I--attest to a general faeling of uncertainty and insecurity. In general, intellectual life at the turn of the century saw a growing awareness by social philosophers and comentators, historians, and artists of the limitations of human knowledge and the subjective character of the cognitive process.. The positivists still assumed the universe to be an integrated system governed by the laws of mathematics. They assumed the structure of both physical and social reality to be discemible through the methods of the natural sciences.

During this period the positivists and their view of the world came under increasing attack. Friedrich Nietzsche, Wiihelm Dilthey, Henri Bergson, Sigmund Freud, Benedetto Croce, Max Weber--these were a few of the thinkers who questioned the validity of the positivist claim for scientific objectivity in social analysis: Historians and social scientists no longer concentrated on the problem of what

19 Fricz Stern, The Politics of Cultural Despair (New York: Doubleday and Co., 1961).

20 George L. Mosse, The Culture of Western Europe: The Nineteenth and Twentieth Centuries (New York: Rand NcNa11y, 1961), pp. 277-292.

$21_{\mathrm{H}}$. Stuart Hughes, Consciousness and Society: The Reortentation of European Social Thought, 1890-1930 (New York: Vancage, 1958). 
constituted society or history; instead they asked how a science of history or society was possible and, if so, how it might be constructed. Philosophers no longer searched for ultimate truth within a metaphysical framework, but attempted to answer questions of the epistemology and logic of historical thought and to do comparative and historical studies of different philosophies and ideas.

The "revolt against positivism," however, did not reject all. the tenets of positivism. Dilthey, Weber, Freud, and others all shared the positivist regard for the empirical fact. They wanted to eliminate all speculative basis for modern thought, but they retained a strong faith in scientific method as a means for gaining knowledge of realicy. They did not believe, however, that all meaningful activm ity was rational, as the positivists did. They had a strong faith in the cognitive process and in logic as vehicles for finding meaning, but there was an equal recognition of the irrational, the enotional, the passionate: Dilthey's Erlebnis, Bergson's elan vital, Freud's concept of the $i d$; for example, all represented an effort to find rational categories and explanations for the irrational. 22 . Implicit, also, was a belief in history as a meaningful process. History and change was process, these thinkers believed, and was therefore discemable by rational analysis. Irrationality does not defy analysis, but is part of a process that can be discovered by scientific incerpretation of phenonenal data.

${ }^{22} \mathrm{CE}$. Willson $\mathrm{H}$. Coates and Hayden V. Wite, The ordeal of Libera1 Humanism (New York: McGraw-Hi11, 1970), Vol. 2, pp. 256-262, $270-284$. 
The essential characteristic of the "crisis" period in European thought, then, consisted in the revolt against positivism, against the belief in the rational systematic nature of all physical and social processes. The validity of scientific method as a tool for knowing reality was not rejected; nor was the belief in the validity of the empirical fact. A systematic, logical method was used by these thinkers to deive into the realm of the irrational, to rationally understand subjectivizy and irrationality.

Cassirer followed his contemporaries in looking for a synthetic method for analyzing reaiity. He had a profound belief in the value of the phenomenal fact and: the scientific rethod, coupled with a rejection of any speculative explanation of reality. He saw the essential nature of the "crisis" in European philosophy to be a confilct bezweenempiricists and idealists, between positivists and metaphysicians, between rational ideation and phenomenological experience:

What would saem to constitute the bias of 'empiricism' as veil as abstract 'idealism'. is precisely that neither of them fully and clearly develops this fundamental relation. One posits a concept of the given particular but fails to recognize that any such concept must always, explicitly or implicitly, encompass the defining attributes of some universal; the other asserts the necessity and validity of these attributes but rails to designate the medium through which they can be represented in the given psychological world of consciousness. 23

"Idealism" refuses to recognize the empirical, phenomenological basis of reality: "empiricism" fails to explain how empixical reality is cogitated in the "world of consciousness."

23. Ernst Cassirer, Philosophy of Symbolic Forms: Language, trans. R. Manheim (New haven: Yale Lniversity Press, 1953), p. 110. 
"If, however," Cassirer continued, "we start not with abstract postulates but from the concrete basic form of spiritual life, this dualistic antithesis is resolved. The illusion of an original division between the intelligible and the sensuous, the 'idea' and 'phenomenon' vanishes." 24 The "concrete basis for spiritual 1ife," Cassirer contended, is found in the symbolic function, in the epistemological process described by the "philosophy of symbolic forms."

Cassirer saw his departure point, then, in the recognition of the "crisis" situation in European philosophy, and his mission in the exposition of a new "center,". one that would provide a "conceptual unity" to the anarchy of cultural and scientific data. 25 His "phi: Losophy of symbolic forms" was intended to provide that "unity." "The main tenets of Cassirer's philosophical system will be presenced. be1ow.

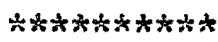

The assumption pervading all of Cassirer's method, the cornerstone of his philosophy; is the belief in the existence of a universal cogritive faculty, of man's abillty to reason. Further, "of all cultural Eorms, only that of logic, the concept, cognition, seems to enjoy a true and authentic autonomy ${ }^{326}$. The most significant contribution in the history of philosophy came from the Greeks, Cassirer

24 Ibid., pp. 110-111.

25 Essay, p. 24 .

26 philosophy of symbolic Forms: Language, p. 63. 
believed. The idea of a universal logos, a universal order, was a means of comprehending reality that entailed a transcendence of mere sympathetic understanding: "From the time this thought first permeated the school of Greek philosophy, all knowledge of reality was bound to a certain extent, by this basic concept of 'logos'--hence, by 'Iogic' in the widest sense." 27 It has enjoyed a "true autonomy," despite its variations in the systems of different intellectual trends. 28 Logic's function has remained the same, to deal with reality, to mediate experience, to symbolize phenomenal life into cultural forms. Logic and the concept 29 are functional forms that are a part of the cogarive faculty. Indeed, the very attribute separating man from the animal world as well as tying him to it is his ability to cognate, to reason. He is a part of the organic world and can never break out of that wor1d. But he can know the limits of that world, and can understand his connection to it through the cognitive process.

Cassirer maintained the proper goal of philosophic inquiry to be self-knowledge, the process of coming to know the limitations as we11 as the possibilities of human life and culture. Philosophy should be anthropomorphic, it should focus on defining the nature of man, and it should discover nan's role in a universe that "sets no limits to. human reason." 30 Beginning with Plato, Cassirer sketched the genesis

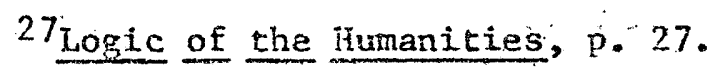

28 Ibid., pp. $46-47$.

${ }^{29}$ Cf. Cassirer, Philosophy of Symbolic Forms: Phenomenology of Knowledge, trans. R. Kanhein, (New Haven: Yale University Press, 1957), pp. 279-314.

30 Essay, p. 17 . 
of concepts of the nature of man, seeing the crucial change coming with the acceptance of the Copernican system by philosophers and scientists. Montaigne's words-m"that man alone is able to value things according to their true estimate and grandeur"--are taken by Cassirer as a

.. - clue to the whole subsequent development of the modem theory of man. Hodern philosophy and modern science has had to accept the challenge contained in these words. They had to prove that the new cosmology, far from enfeebling or 'obstructing the power of human reason; estabiished and confirms this power. 31

Such has been the ain of philosophy, he belleved, and such was the stated aim of his own thinking.

The "crisis" of modern philosophy was the condition, cognitive philosophy was the means, and self-knowledge was the aim of Cassirex's mission, his search for the "clue of Ariadne." This clue, he believed, could be found in the symbolic function. The primary characteristic of the human world distinguishing it from the animal world is man's ability to symbolize experience in art, religion, nyth, history, and science. Between the "receptor system" and the "effector system"between the stimulus effection and the resporse articulation-lies the "symolic system." 32 It is an artificial medim, "a symbolic net, the tangled veb of human experience." 33 To be sure, the cognttive faculty is possessed by all humans, but it is an inadequate cerm, Cassirer believed, to express the symbolizing function of man. Instead of being defined as an. "animal racionale," he should be derined as

$$
\begin{aligned}
& 3 I_{\text {Ibid.., p. } 16 .} \\
& 32 \text { Ibid., p. } 26 . \\
& 33_{\text {Ibid., p. } 27 .}
\end{aligned}
$$


an "animal symbolicum." 34 An analysis of this function, then, provides a path out of the "labyrinth" and provides a conceptual unity for understanding both cuiture and science, Cassirer argued.

The beginning point for such an analysis, for delfneating the symbolic function, cones with a definition of speech: "All culcure forms are "active expression forms. "35 "rmotional language" and "propositional language" are the two types of language found in the organic world. A11 language has a certain "emotional tinge," 36 but "enocional language" proper belongs to the anima? world and, as Cassirer sometimes called $i t$, the "primicive world." Man gives expression a theoretical form, he objectifies experience of phexomena through language, he symbolizes: ". - the animal possesses a practigal imagination and intelligence whereas man alone has developed a new form: a symbolic imagination and incelligence:" 37

Cassirer retold the story of Helen Keller's development of. vexbal skills as an tilustration of this tenet ${ }^{38}$. The day she learned everything has a name, and that the manual alphabet is the key to understanding these names, she began to see relations, to abstract function, to symbolize: "It had to be understood that everyching has a name--that the symbolic function is not restricted to particuiar

$$
\begin{aligned}
& 34 \text { Ibid., p." } 28 . \\
& \text { 35 Logic of the Humanities, p. I0. } \\
& { }^{36} \text { Essay; p. } 31 . \\
& 37 \text { ridd., p. } 36 . \\
& { }^{33} \text { Ibid. pp. } 36-39 \text {. }
\end{aligned}
$$


cases but is a principle of universal applicability which encompasses the whole field of human thought."39 "Propositional expression" concentrates not on the content of language--the substance of language-but on the process, the function of language. Only in the function of theoretical language can we discover a universal principle. Substance varies Erom language to language, even within any one language; but the symbolic function is the same for all. All human languages demonstrate the propositional, the theoretical, the symbolic form of human experience.

Man's capacity. to view relations between experiences, to isolate those relations in the abstract, is also dependent, is a part of, symbolic thought. All relational thought, all reflective thought, is contingent on the symbolic process. It frees man from a life"... confined within the limits of biological needs, and practical interests." It gives man ". . access to the 'ideal vorId' which is opened.. . from different sides by religion, art, philosophy, science. ${ }^{40}$

An essential facet of this symbolic process, Cassirer argued, is the unique human view of time and space, "Indeed," the type of time and space man operates in. The lonest stratum of time and space is "organic." 41 Animals follow instinct and "bodily impulses"42 in

$$
\begin{aligned}
& 39 \text { Ibid., p. } 40 . \\
& 40 \text { Ibid., p. } 45 . \\
& 4 I_{\text {Ibid. }} \text { p. } 26 . \\
& 42 \text { Ibid., p. } 47 .
\end{aligned}
$$


their experience, without any semblance of any ideational processes. Man also acts within this realm of "organic space," but he works in another, higher, stratum when he begins to ideate, to symbolize. He begins to work within an abstract of "symbolic" space. 43 Like the space of geometry, it is a ". . homogeneous, universal space: it was only in the medium of this new and characteristic form of space that man could arrive at the concept of unique, systematic, cosmic order." 44 In this space appearances are not merely handled, they are. represented and their relations considered.

Cassirer made some of the same distinctions when dealing with time. "Organic" time is a process, a stream of events, where past; present, and future are joined in a constant movement. In the animal world, experience is a part of that movement, and time is never abstracted. Universal, time, the time of thuman culture, is to be found. in the human ability to remember. In memory, Cassirer asserted, former impressions are "rot only repeated, but must also be ordered. and located, and referred to different points of time." 45 In order . to do this, time must be considered as a general scheme, as a "serial order." 46 In the ideational process man arranges events in sequential orders within comprehensive schemes. And it is not the facts, the contents of these memories, that give the scheme its universai meaning.

$43_{\text {Ibid. }}, \mathrm{p} .48$.
44 Ibid., p. 50
45 Ibid., p. 56.
46 Ibid., p. 57. 
It is, once again, the conceptual form, the functions of the contencs that demonstrate the universality and meaning of the scheme: "The 'Integral' of consciousness is constructed not fron the sum of its. sensuous elements $(a, b, c, d, \ldots$. . ), but from the totality, as it were, or its differentials of relation and form $\left(d r_{1}, d x_{2}, d x_{3}, \ldots . .\right)^{117}$. Meaning is not derived from the contents-the "sensuous elements"of the serial order in memory ("consciousness"); but from the relations and functions of those contents. Past experlence is not just repeaced in memory, it is reconstructed; and this reconstruction process is a universal characteristic of man It is a symbolic process, utilizing the phenomena of the past... The poetic imagination and historical Inquiry both play a part in this recollection process.

Cassirer did not exclusively concentrate on the relation of the present to the past, however. He also defined what he cailed "the dimension of the future." 48 He identified the existence of a "theoretical idea of the Euture," one that is a prerequisite for all cultural activities. 49 . It is, essentialiy, the "symbolic future," . the capacity of man to formulate ideals or symbols of his future." In this sphere lies man? essential freedom, the freedorn to conceptualize utopias, to forsee, to prophesy, to plan the future. Symbolization of the future makes". . roon for the possible as opposed to passive acquiescence in the present state of affairs. It is symbolic thought

${ }_{47}$ Philosophy of Symbolic Forns: Language, p. 105. 48 Essay, p. 58. 49 Ibid., p. 60 . 
which overcomes the natural inertia of man and endows him with a new ability, the ability constantly to reshape his human universe." 50 With universality and "conceptual unity" as criteria, Cassirer elevated process over content, function over substance. The former precludes the latter. Only in function can man find universality, a "conceptual unity" that encompasses ". . not only the cosmos of nature but also that of culture." Cassirer maintained the only valid analysis of culture must limit its scope to man's "vork." 51 . It must concentrate on the creative process, the creative function.

It is this work, it is the system of human activiries, which defines and deternines the circle of 'humanity." Language, nyth, religion, art, science, history are the constituents, the various sectors of this circle. A "philosophy of man". would therefore be a philosophy which would give us insight into the fundamental structure of each of these human activities, and which at the same time rould enable us to understand them as an 'organic whole." 52

The "philosophy of symbolic forms," then, revolves around a method in which function, the elicited need for conceptual unity, the poetic imagination, and rational analysis play major roles. Cassirer used much of the conceptual vocabulary of the "philosophy of symbolic forms" when discussing his method of doing history, as will be seen in the following chapter.

50. Ibid., p. 68.

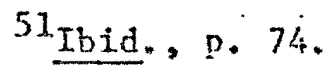
52 Ibid. p. 74. 
CHAPTER IV

SYMBOLIC RECONSTRUCTION, FUNCTION," AND STRUCTURE:

THE PARADIGI

It might be possible to maintain that Cassirer's view of history merely an extension of his epistomelogical views, of his "philosophy of symbolic forms." But to do so would be to neglect Cassirer's real historical achievement. It is possible to analyze his methodological paradigm, concentrating on how it is used in his historical works, without extensively considering his epistemological dispositions. The former chapter was included only to familfarize the reader with. some of the terminology and concepts Cassirer uses in discussing his method of doing history and to demonstrate that Cassirer did make a "response" to the "crisis" situation in European philosophy. Cassirer did believe a scructural orientation is necessary for any historical analysis and synthests: "History itself would be lost in the boundless mass of disconnected facts if it did not have a general structural scheme by means of wich it can classify, order, and organize these facts." 53 But a full comprehension of his "philosophy of symbolic fonu" is not necessary for understanding his particular structural orientation, for understanding the paradigm he used for doing history. It right also be possible to maintain that Cassirer was not a historian of ideas, but a historian of philosophy, using the criteria 53 Ibid., p. $75-76$. 
Paul Kristellex uses to delineate the two realns. In an article in the Journal of the Ilistory of Philosophy, Kristeller describes commonly accepted definitions of the two closely related endeavors, the history of ideas and the history of philosophy. The historian of philosophy, Kristeller maintains, concentrates on the relations of a given philosophical idea or problem ". . . to the context of the philosopher who expresses it, and to that of his contemporaries, predecessors, and successors in the history of philosophy." A historian of ideas includes Ideas from the discipline of philosophy as objects of study, but he also works with ideas from att, literature, the sciences, and reliGion,". . within the context of the. . thought with which they may be more or less connected." 54 The historian of philosophy is concerned with problems of philosophy, theit developmerit and philosupirical background, while the historian of ideas deals wh the problems of science, art, literature, religions, as well as philosophy.

Cassirer claimed philosophy and the history of philosophy as his realins of operation. But he gave a special and quite broad defintion to philosophy. Philosophy should focus on defining the nature of man, Cassirer maintained. It should center on a delineation of the limitations as well as the potentialities of cultural life. Philosophy provides the milieu in which culture formulates its ideas and principles. Cassirex's statement of purpose in the preface to the Philosophy of the Enlightenment best sumarized his view of philosophy.

54Paul Kristeller, "The History of Philosophy and the History of Ideas," Journal of the History of Philosorhy, Tol. 2 (1264), p. 13. 
Such a presentation of philosophical doctrines and systems endeavors as it were to give a 'phenomenology of the philosophic spirit'; it is an attempt to show how this spirit, struggling with purely objective problems, achieves clarity and depth in its understanding of its own nature and destiny, and of its own fundamental character and mission ... Philosophy, according to this interpretation, is no special field of knowledge situated beside or above the principles of natural sclence, of law and government, etc., but rather the allcomprahensive medium in. which such principles are formulated, developed and formed. Philosophy is no longer to be separated from science, history, jurisprudence, and politics; it is rather to be the atmosphere in which they can exist and be effective. Philosophy is no longer the isolated substance of the intellect; it presents the totality of the intellect in its true function, in the spacific character of its investigations and inquiries, its methods and essential cognitive process. 55

Cassiter gave philosophy a special importance, one that was closely tied to his assertion of the need for a structural orientation in approaching historical facts. In his writings the history of philosophy is the history of ideas. If includes any ideas and cultural expressions that might be a part of the "all-comprehensive mediun" in which science, history, jurisprudence, and politics exist and operate. With this in mind, an examination of Cassirer's systematic method, his "symbolic reconstruction" paradign, can be examined.

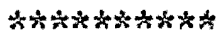

The beginning point in any analysis of .Cassirex's method lies in a consideration of that he believed constitutes a historical "fact:" Historical "Facts" obviously. do not have a material or physical existence and meaning, and any historical "fact" can be understood only

55Rrust Cassirer, The Phtlosophy of the Enlightenment, trans. Fritz C. A. Koelin and James P. Pettygrove (Boston: Beacon Press, 1965), pp. vi-vil. 
through analysis of that meaning. He therefore emphasized "monuments" as the first index of historical "facts":

What is actually preserved for us from the past are specific historical monuments: 'monuments' in word and writing, in picture and bronze. This first becomes history for us when in these monuments we see symbols, through which ve not only recognize specific forms of 1 ife, but by virtue of which we are able to restore them for ourselves. 56

The historian, like the scientist, lives in the physical world. But the data of history, unlike those of the natural sciences, is not initially physical or material. Historical "facts" acquire a physical, objective meaning only through an analysis of their symbolic meaning. The historian aiscovers "facts", through the mediation of symbols: "Not rhings or events but documents or monuments ate the first and immediate objects of our historical knowledge. Only through the mediation and intervention of these symbolic data can we grasp the real historical datam-the events and the men of the past." 57 Historical "facts" are symbolized in "monuments" and documents. The historian returns to these "facts" through an analysis of this symbolic data. "Symbolic reconstruction" is the label Cassirer gave to the process of interpreting this "symbelic data." Symbolic data is gathered and "remembered.". Critical judgments are made, the data is arranged In serial order in time and space, further fudgments are made, the "facts" in the "monument" axe discerned, more reconstruction taises place, and eventually the historical event in all its significance is depicted. The process is not one of simple reproduction of the past.

56 Logic of the Humanities, p. 146 .

57 Essay, p. 193. 
Cassirer recognized the impossibllity of such an endeavour. Historical analysis is a recreation, he said, a "new intellectual synthesis, a constructive act." 158

The meaning of a historical "fact" can never be discemed without this reconstruction. An attempted reproduction and isolation of the event would give only a smali portion of the meaning, Cassirer contended. The historian's work is never done. Historical analysis and synthesis is an endless assignment. No single "reconstruction" has a purely objective certitude, but sust be subjected to continual analysis in the fucure.

The "constructive act," again, demands the historian to make interpretive judgments on the data before him. These judgments have a double face. They are necessarily subjective, but the his $\rightarrow \ldots$ torian must strive for objectivity. He cannot excape his own experience and predelictions when making judgments. He should, however, be aware of his passions without baing passionate: "History is a history of passions, but if history attempts to be passionate it ceases to be history." 59 Judgments about the past are inescapably subjective, Cassirer believed. But they are also objective in that they force the investigator to enlarge his perspective beyond the imediacy and pure subjectivity of the monent:

By making us cognizant of. the polymorphism of human existence it [history] frees us from the freaks and prejudices of a

$$
\begin{aligned}
& { }^{58} \text { Ibid., p. } 204 . \\
& 59_{\text {Essay, p. }} 211 .
\end{aligned}
$$


special and single moment. It is this enrichment and enlargemenc, not the efracement, of the self, of our knowing and feeling ego, which is the aim of historical knowledge. 60

History does not concentrate on the Individual ego, but on the collective man. It is anthroponotphic. But objectivity remains a goal for the historian. History and historical judgments comprise an "objective anthroponorphism." 61

Enlargement of the self--"objective anthropomorphism"--Is the aim of historical analysis and judgment. Logic is the means. The doing of history is a hermeneutfal process, an interpretation procedure, entalling a logical analysis of symbols as they exist in "monuments," in documents, in the phenomena of the past. Historical judgments are therefore both universal and particular. Historical analysis does not have a logic of its own, for logic is universal. Judgments are universal because logic is universal. They are universal it function, as ".. . thought is always universal." 52 . But they are a1so particular in their orientation because they deal with particular historical phenomena. Judgments are a unity in multiplicity, a multiplicity in unity. Analysis and synthesis of particulars are inextricably conjoined by the rules of universal logic.

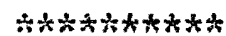

The form and function of ideas, rather than their substance and content, is of primary interest in "symbolic reconstruction.".

\footnotetext{
${ }^{60}$ Ibid.; p. 212.

6 Irid., p. 211.

62 Ibid., p. 206.
} 
Historical meaning resides in becoming; it is not merely a category of being. . Symbols must be analyzed--"monuments" and "worik" must be examined--in terms of their function in the stream of cultural ideation. Meaning is not temporal and static, it.is systematically. functional and dynamic. There is a certain continuity in substance, Cassirex believed. Certain ideas change slowly in their content. But the function of these ideas can change dramatically, giving meaning to an entire age. Cassirer best stated this concept through a river metaphor, then discussing the "originalizy". of the Renalssance:

Nevertheless the distnction [between. Mddie Ages and Renaissance] ias a real meaning. What we can express by it, and what alone we incend to express, is that from the beginning of the fifteenth century onward the balance between the particular. forces-msociety, state, reigiton, church, art, science-begins to shift slowly. New forces press up out of the depths and alter the previous equilibrium. And the character of every culture rests on the equilibrium batween the forces that give it form. Whenever, therefore, we make any comparison between the Middle Ages and the Renaissance, if is never to single out particular ideas or concepts. What we vant to know is not the particular idea as such, but the importance it possesses, and the strength with which it is acting in the whole structure. 'Middle Ages' and 'Renaissance' are two great and mighty streams of ideas. When we single out from then a particular idea, we are doing what a chemist does in analyzing the water of a stream or what a geographer does in trying to trace it to its source. No one denies that these are interesting and important questions. But they are neither the only nor the more important for the historian of ideas.

The historian of ideas knows that the water which the river caxries with it changes only very slowly. The same ideas are always appearing again and again, and are maintained for centuries. The force and the tenacicy of tradition can hardly, be overestimated. From this point of view. we must acknowledge that there is nothing new under the sun. But the historian of ideas is not asking primarily what the substance is of particular ideas. He is asking what their Eunction is. What he is studying-or should be studying--is less the content of ideas than their dynamics. To continue the figure, we could say that he is not trying to analyze the drops of water in the river, but that he is seeking to measure its width and depth and ascertata the force and velocity of the current. It is all these factors. 
that are fundamentally altered in the Renaissance; the dynamics of ideas have changed. 63

The "function" of ideas, then, consists of their "dynamics" in relation to the "equilibrium betiveen the forces" that give a culture its form. The historian must focus on how ideas are used by different thinkezs, how these ideas "function" as cultural expressions in the cultural milieu.

For example, the view of knowledge elucidared by Nicholas Cusanus in De docta ignorantla yepresented a "compietely new rotal incellectual orientation, "164 on that was co play a tatjor role in the systems of later thinkers, one that was ro make Cusanus "the first modem thinker." 55 Quite simply, Cusanus argued that the two types of reality, the absolute and the empitical, the infinite and the finite, are conjoined in the vay they are known. The empirical finite world can be known positively, through comparison and measurement, and the absolute infinite reality can then be defined in terms of what it is not, in terms of what the finite world is. ${ }^{66}$. This concept of knowledge, as it was explained in detail in De docta ignorantia had a role in the systems of later thinkers, Cassirer believed. It was significant both in the possibilities it offered and in the

${ }^{63}$ Ernst Cassirer, "Some Remarks on the Question of the Originaliry of the Renaissance," Journal of the History of Ideas, Vol. 4 (1943), p. 5.5 .

${ }^{64}$ Ernst Cassiter, The Individual and the Cosmos in Renaissance Philosophy, trans. Mario Domandf (New York: Barnes and Noble, 1963), D. 10.

$$
\begin{aligned}
& 65_{\text {Ibid. }} \text { p. } 10 . \\
& 66_{\text {Ibid., }} \text { p. } 11 .
\end{aligned}
$$


orientation it took. Indeed, it constitured the single most important doctrine in the thought of the Renaissance, and its iraportance was a functional one. 67

Shaftesbury"s concept of "disinterested pleasure," 68 Lessing's view of rationality, 69 Rousseau's idea of the "state of nature"70-these and other ideas were explained by Cassirer in functional tems. For example, Lessing's view of rationality-mat reason, as it is imanent in history, provides a guide to natural religious truth--is important because of its role in later theorizing on history:

He [Lessing] has always been the great rationalist, and he remained so to the last; but he replaces analytical reason with synthetic reason, and static reason with -dynamic reason. Reason does not exclude motion; it seeks rather to understand the immanent law of motion. It is reason itself that now plunges. into the stream of becoming, not in order ta be seized and carried along by its swirls but in order to find here-its own security and assert its stability and constancy. In this -idea of reason we have the dawn of a new conception of the nature and truth of history which could not achieve maturity, perfection, and confirmation in the realm of theology and metaphysics. It is Herder who takes the last and decisive step in this development when he directs his question at historical reality as a whole and tries to answer it on the basis of the concrete evidence on its phenomena. But Herder's contribution is only in appearance an isolated achievement. It does not'represent a break with the thought of the Enlightenment but evolves slowly and steadily from this thought and

67 Ibid., p. 7; also see 10f, 23f, 41, 56; for its role in the thinking of Eicino, $63 \mathrm{f}$; in Pico's thinking, $87 \mathrm{f}$.

68 Ernst Cassirer, The P1atonic Renaissance, trans. J. p. Petrygrove (Austin: University of Texas Press, 1953), p. 195.

$69 \mathrm{philos}$ ophy of the Entiphterment; p. 195.

70 Ernst Cassirer, Rousseau, Kant; Goethe, trans: James Gutmann, Paul Kristeller, John H. Randal1, Jr. (Princeton: Princeton University Press, 1247), p. 10. 
matures on its soil. The problem of history for the philosophy the Enlightenment arises in the field of religious phenomena, and it is here that this problem first becomes urgent. 71

Lessing's "idea of reason" was important for the role it played in his own philosophical system. But it was also signtacant because it represented the "dawn of a new conception of the nature and truth of history." His "idea of reason" had a functional importance in later theorizing on history. Further, Spinoza, Lessing, and other Enlightenment thinkers produced ideas that, in their functional development, played a part in Herder's thinking on history and eventually contributed to the opening of the. "thole horizon of the historical world." 72

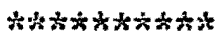

Cassirer was fairly consistent in this emphasis on function, on synthesis, and on the dynamics of ideas. He was also consistent in the manner in which he approached these dynamics, in the method he used to identify those cultural functions that characterized a particular thinker, group, or age. He usually began, at least ostensibly, with the individual and the phenomena of the individual's "rorks," moved into broader generalizations about groups of thinkers and concepts, and eventualiy came to some conclusions about the "spirit" of the age.

71. The Philosophy of the EnIfghtenment, pp. 195-196.

72. Ibid., p. 106; also cf. 182-196. 
"Rousseau's fundamental thought," Cassirer argued, "puts before us an objective formulation of questions; and this formulation is valid not for him or his era alone but contains, in full sharpness. and definiteness, an inner, strictly objective necessity." 73 He attempted to delineate the "systematic core" of Rousseau's "fundanental idea," 74 and concludad that Rousseau was a "true son of the EnIIghtenment, even when he attacks it and triumphs over it."75. Similarly, Nicholas Cusanus represented the focal point, the polnt of departure. of the Quattrocento: "His thought blossoms out of one intellectual seed (De docta ignorantia) that progressively unfolds and, in this process of unfolding, absorbs the entire range and the entire Problematik of knowledge in the Quatrocento." 76 Newton and Leibniz represented two alternative "fundamental philosophic methods": "hodern thought had reached a parting of the ways where it had to choose between two alternatives. In the dispute between Newton and Leibniz these alternatives were clearly indicated." 77

When analyzing. the Cambridge Platonists, Cassirer concentrated more on the philosophy of the group as a coherent "whole" than on the individuals within the group. But still, he purported to show

${ }^{73}$ Ernst Cassirer, The question of Jean-Jacques Rousseau, trans. Peter Gay (New York: Columbia University Press, 1954), p. 40.

74 Philosophy of the Enlightenient, p. 253 .

$75_{\text {Ibid., p. } 274 .}$

76 The Individual and the Cosmos, p. .7.

77 Ernst Cassirer, "Newton and Leibniz," The Philosophical Review, Vo1. 52 (1943), pp. 366 . 
how they represented a "genuine ancient philosophical tradition."78

His statement of intent in this essay gave a good metaphorical sumary

of his method.

What this study has intended to show is this: that the problems with which the Cambridge men wrestled are not antiquated, but have entered direetly into the formation of the modern phi1osophical world; and that their influence in an altered form persists today. The Cambridge School forms a sort of connecting-link between minds and epochs; it is one of the plers of that bridge linking the Italian Renaissance with German humanism of the eighteenth century. The course of the history of thought does not advance from peak to peak; and the history of ideas cannot be adequately treated, if, as is still the practice of the historian of philosophy, consideration is given only to the great philosophical systems. If one would understand the significance of ideas, one cannot overlook their imanent structure. But our insight into this structure is possible only when, instead of concentrating our attention exclusively on the high points of the great systems, we take our way through the valleys and from there by a gradual and patient ascent work our way up to the peak. 79

Cassirer's analysis moved from the individuals--the "valleys"--to the "spirit" or "mind" of the epoch, the "peaks" in the range.

The same method was explained in his introduction to The Phi--

losophy of the Enlightenment:

The real philosophy of the Enlightenment is not simply the sum total of what its leading thinkers--Voltaire and Montesquieu, Hume or Condillac, d'Alembert or Diderot, Wolff or Lambert--thought and taught.. It cannot be presented in a summation of the views of these men, nor in the temporal sequence of their views; for it consists less in certain individual doctrines than in the form and manner of intellectual activity in general. "The fundamental intellectual forces with which we are here concerned can be grasped only in action and in the constantly evolving process of thought, only in process can the pulsation of the inner intellectual life of the Enlightenment be felt. 80

78 The Platonic Renaissance, p. 202.

79 Ibid., p. 201.

80 The Philosophy of the Enlightenment, p. ix. 
By artalyzing the doctrines of Individuals and synthesizing those

functional elements representing the epoch, the "philosophy of the Enlightenment" was defined. Cassirer followed the same procedures in his other historical works.

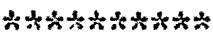

In synthesizing the dynamics of the "formation of modern thought" Cassirer concentrated on the problems different thinkers discuss, rather than the relaged themes of their ideas, on Rroblematik rather than lhematik. He was interested primarily in the questions asked rather than the solutions reached, an emphasis corresponding to his concentration on function and on the dynamics of thought. Ideas are problematical in their development, he contended. Their "full determination" in any other terms can take centuries:

The history of philogophy shows us very clearly that the full determination of a concept is very rarely the work of that thinker who first introduced that concept. For a philosophical concept is, generally speaking, rather a problem than the solution of a problem--and the full significance of this problem cannot be understood so long as it is still in its first implicit stage. It must become explicit in order to be comprehended in its true meaning, and this transition from an implicit to an explicit state is the work of the future. 81

Concepts are only illusively static in their initial statement, Cassiter believed. They should be seen in terms of the questions they pose and the function they have in the development of thought. Only then can "full detemination" of any. idea be comprehended.

$81_{\text {Essay, pp. } 199-200 .}$ 
Some problems are so pervasive in specific historical periods as to characterize those periods, Cassirer believed. One of the most significant problems of the Renaissance, for example, was the question of the subject-object relationship, of the interaction between finfte ego and infinite cosmos:

Man, the Ego, appears to the Universe, the world, at once as the enclosing and the enclosed. Both determinations are equally indispensable to express the relationship to the cosmos. And. thus a continuous mutual reaction and continuous interaction takes place between them . . The Ego can face the infinite cosmos Inasmuch as it finds within itself the principles by which it knows that the cosmos is infinite. But this.knowledge itself is not of a merely abstract or of a purely discursive kind. It is an intuitive certainty that springs, and continuously rushs forth, not from the logical intellect but from the specific and vital principle of the Ego . . The philosophy of the Renaissance never resolved the dialectical antinomy that is enclosed in this double relationship. But it has the indisputable mexit of having determined the problem and handed it down in a new form to the following centuries, the centuries of exact science and systematic philosophy. 82

The "dialectical antimony" between Ego and the Cosmos was the most characteristic problem of Renaissance philosophy, Cassirer argued. And it had a functional importance that transcended the epoch, that played a role in the thinking of "following centuries."

Cassirer also used a problem approach to the ideas of the Cambridge Platonists. Some of the questions they considered, he contended, were of considerable significance in the development of the European "mind":

Here, within a narrow circle of thinkers: and in a remote section of the learned vorld, questions were being hammered out which are to affect the very conception and structure

82The Individual and the Cosmos, pp. 190-191. 
of the modern mind. The following considerations endeavour to show in what light the Cambridge School viewed these questions, under what presuppositions it formulated them, and by what means it tried to solve them. 83

When discussing the Cambridge Platonists, as in his discussions of other historical periods, Cassirer asserted a belief in the recurrence or even continuity of specific problems in different chronological periods. His contention that there "is nothing new under the sun" except in the manner in which problems function in the "stream" of ideas is seen in the above example, as in others. 84 A focus on tine characteristic problems of each period, and then on their dynamic role in the making of the "modern mind" is seen in all of Cassirer's historical writings.

It can be argued, of course, that such an emphasis transforms dynamics into statics, that an analysis and synthesis of function transforms it into something substantial, something other than what it is. But such is the procedure of "symbollc reconstruction." The historian cannot reproduce history; it must be recreated. In the process, certain unities of functional serial orders are defined. These unities became historical substance within the content of . Cassirer's synthesis.

$* * * * * * * * * *$

These functional unities do not have a real existence in a particular epoch, but are heuristic, logical unities. They serve

83 The Platonic Renalssance, p. 7.

${ }^{84}$ See above, p. 26. 
only to explain, not to describe the reality of the epoch. When discussing the dispute over Burckhardt's definition of the Renaissance, Cassizer outlined one of these unities:

Our controversy as to the originality of the Renaissance and as to the dividing-line between the "Renaissance" and the 'Middle Ages' seems to me in many ways rather a 'logical' dispute than one about historical facts. Ideas like 'Gothic," 'Renaissance,' or 'Baroque' are ideas of historical 'style." As to the meaning of these ideas of 'style' there still prevails a great lack of clarity in many respects. They can be used to characterize and interpret intellectual movements, but they express no actual historical facts that ever existed at any time. 'Renaissance' and 'Middle Ages' are, strictly speaking, not names for historical periods at all, but they are concepts or 'Ldeal types;' in Max Weber's sense. We cannot therefore use them as instruments for any strict division of periods; we cannot inquire at what temporal point the Middle Ages 'stopped' or the 'Rennaissance' began. The actual historical facts cut across ang extend over each other in the most complicated manner.

He discussed this concept of "unities" more carefully in The Logic

of the Humanities.

What we are trying to give expression to here is a unity of direction, not a unity of actualization. The particular individuals belong together, not because they are alike or resemble each other, but because they are cooperating in $a$ common task, which, in contrast to the Middle Ages, we perceive to be new and to be the distinctive 'meaning' of the Renaissance. All genuine concepts of style in the humanities reduce, when analyzed more precisely, to such conceptions of meaning. The artistic style of an epoch cannot be determined unless we gather into a unity all its divergent and often patently disparate artistic expressions . . Such expressions do indeed characterize but they do not determine; for the particulars which they comprehend cannot be deduced from them.

But it is equally incorrect to infer from this that we have only intuitive description here, and not conceptual characterization; we are dealing with a distinctive manner and direction or characterization, with a logico-intellectual activity which is sui generis.

85 "Some Remarks on the Question of the Originality of the Renaissance," pp. 54-55."

86 The Logic of the Humanities, pp. 139-140. 
Cassirer's concept of "logico-intellectual" unities of meaning based on historical "style" is not one of his clearer ideas. It tied in closely with his advocacy of the need for a "general structural scheme" by means of which "it [history] can classify, ordex; and organize.. facts." 87 An analysis and synthesis of the common questions asked by a group of thinkers and of the function those questions have in the intellectual systems of those thinkers as weil as in the thought of later thinkers expresses a "unity of direction,". a "characterization" of an age. The category of "characterization"-the "Renaissance," the "Enlightenment," the "modern mind," etc;-does not have a real historical existence. The "characterization" does not describe the reality of the period. The particular facts of the historical reality cannot be deduced from the "characterization.". But the particulars--the "facts" discerned behind the "monuments"are grouped by the historian according to their commonality of function and their unity of "direction." The resulting synthesis is a heuristic one, a "logico-intellectual" category which is sui generis, which interprets the "Intellectual movement" but does not embody its specific historical reality.

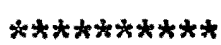

Empirical analysis-"symbolic reconstruction"--of the "monuments" combined with imaginative recreation of the "facts" behind the "monuments" produces historical knowledge. A close analysis and synthesis $87_{\text {Essay, pp. } 75-76 .}$ 
of the "monuments," centered on Problematik and function, yields those meaningful unities which constitute history. And this knowledge has a special place in the "organism of human"clvilization," Cassirer maintained. 88 It is a necessary component of man's self-knowledge, "an indispensible instrument for bullding up our human universe. " 89 By understanding man's "works"-his cultural expressions--in the past and by recreating the history of the creative process, Cassirer believed man can better view his own potentialities. Historical memory is a necessary component of: Man's future life and of his freedom. Cassirer believed history to be the process of revealing man to himself, that he can better free himself of the limitations placed upon him by contemporary cultural expressions. Historical reconstruction embodies this freedom. In history and in the historical perspective exists the objective proof of humistic potential, of man's consciousness, of freedom in necessity.

${ }^{88}$ Ibid., p. 228.

${ }^{89}$ Ib1d., p. 228. 


\section{CHAPTER V}

FUNCTION AND THE RAGE.FOR COHERENCE:

THE PARADIGM CRITICIZED

It would be an overstatement to say Cassirer left no loose ends 1ying about. Despita his penchant for structural "untties" he was simply not as systematic as he wanted to be. The Philosophy of the Enlightenment, for example, appears to be a collection of connected essays, rather than a systematic work defining, in all its unity, the "mind" of the Enlightenment. Nevertheless, Cassirer intended to be coherent and systematic and he intended his works to be seen as related unities. He constantly referred back to his earlier works when writing about certain topics. He saw his varlous works on history as having organic connections, much as he saw the relationships between the epochs he was analyzing. And he made statements of intent within each work that belie any attempt to see his works as anything but systematic unities. For example, in the introduction to The Individual and the Cosmos in Renaissance Phtlosophy he stated his intent accordingly:

What is needed is the universality of a systematic point of view and of a systematic orientation which in no way coincides with the universality of merely empirical concepts used in the periodization of history for convenient classification. To supply this will be the aim of the following study . . . it intends to remain within the realm of the history of philosophtcal problems, and to seek, on that basis, to answer the 
question: whether and to what extent the movement of thought in the fifteenth and sixteenth centuries constitutes a selfcontained unity despite the multiplicity of starting poinrs 90 and the divergence of solutions to the various problems posed.

In his The Platonic Renaissance he stated a similar intent, ${ }^{91}$ as

he did in The Philosophy of the Enlightenment:

The fundamental intellectual forces with which we are here concerned can be grasped only in action and in the constantiy evolving process of thought; only in process can the pulsation of the inner intellectual life of the Enlightenment be felt. . . The present book has tried to accomplish this task, not by endeavoring to give a history of Individual thinkers and their teaching but by means of a history of the ideas of the epoch of the Enlightenment $\ldots$ The alm of this book was simply to develop and to explain historically and systematically the content and point of view of the philosophy of the Enlighteninent. 92

Even Cassirer's revisions of facts could not escape the struc-

tural artifice he created:

I avail myself of this opportunity to revise a former statement made in my Individurm and Kosmos. In the second chapter. I tried to show that Nicholas of Cusa's philosophy exerted a strong influence on the general development of Italian thought in the Quattrocento. I still think this to be highly probable, but. I should perhaps have spoken with more caution. I quite agree that, on the strength of new historical evidence, we can not give a direct and definite proof of this thesis. It is possible that Ficino conceived his general theory independently of Nicholas of Cusa. In this case the close relationship between the two thinkers would be all the more important and interesting from the point of view of the general history of ideas. For it would show us the common background of the philosophy of the fifteenth century--the general intellectual and religious atmosphere of the Renaissance. 93

${ }^{90}$ The Individual and the Cosrios, pp. 5, 6 .

91 The Platonic Renaissance, pp. 5, 7 .

92 The Philosophy of the Enlightenment, pp. ix, $x, x 1$.

93Ernst Cassirer, "Ficino's Place in Intellectual History," Journal of the History of Ideas, vol. 6 (1945), p. 492. 
The structure was of primary importance, and "facts" had to be organized within the structure.

I have therefore chosen to consider Cassiter's works as a fairly consistent unity, despite my criticisms of him for doing the same with other thinkers. It is assumed in the following critique that Cassirer consistently followed a structural paraidgm, and that he refused to sacrifice it to reconcile anomalies. A number of loglcal errors in his works will be criticized, but the maln focus of the criticiṣms will be on his misuse of structure, on his "rage for coherence."

When reading Cassirer, one has difficulty separating structure and facts, metaphysics and phenomenology. His writings are filled with references to "motifs," "essential problems," "cores," "the modern mind," the "Renaissance," the "Enlightenment," and other categories of similar breadth. Cassirer claimed to be using such categortes as "logico-historical ideal types" as heuristic devices to "characterize" a pexiod but not to describe 1 ts historical factuality. 94 However, if his intent is ignored, and these categories are viewed as having some substantive descriptive reality, two further passibilities present themselves. Eash category as a whole can be critiqued for its real historical existence, or the facts within the category can be critiqued similarly.: In the latter case, the category can be seen as the sum of individual realities.

${ }^{94}$ See above, pp. $33-34$. 
The two views, then--that Cassirer used such labels as logical structural devices, or that he used them as descriptive devices-can be critiqued. . If the former view is accepted and Cassirer's categor- : ies are viewed as "logico-historical sui generis," with the meaning in the category itself, then his works defining the "Renaissance," the "philosophy of the Enlightenment," the "core" of Rousseau's thought and others are idealist solipsisms or at best, fictions. Or if the categories are assumed to have some substantive meaning, an abundance of criticisms are ençountered.

Kingsley Price, in an article on The Philosophy of the Enlightenment, critiques the possibility that a "mind of the Enlightenment" did exist. 95 He quotes Cassirer's stated intention:

The real philosophy of the Enlightenment. is not simply the sum. total of what its leading thinkers ... thought and taught. It cannot be presented in a sumation of the views of these men, nor in the temporal sequence of their views, for it consists less in certain individual doctrines than ing the form and manner of intellectual activity in general.

The idea of the "philosophy of the Enlightenment" as some vague composite of individual doctrines in terms of general "intellectual activity" seems an inexplicable illusion to Price. Cassirer warned the readex, Price notes, that he did not intend to discuss "certain Individual doctrines," nor the summation of the doctrines of individual writers. And, ". - having been assured that neither of these is appropriate, without having been given any positive Indication as to

95 Kingsley Price, "Ernst Cassirer and the Enlightenment," Journal of the History of Ideas, vo1. 18 (1957), pp. 101-112.

${ }^{96}$ See above, p. 28 . 
what will do, the phrases 'thought of the elghteenth century,' 'mind of the Enlightenment,' and their fellows remain without meaning for us . - under these conditions the attempt to sumnon an idea of an epoch or a century engaged in thought.collapses utterly." 97 " The idea that the categories have a descriptive substantive meaning fails miserably.

If it is argued, however, that Cassirer concentrated on individual thinkers and their ideas in his historical works, and that his categories were merely composites of these ideas, he is. Iiable to even more citticism. He confused the structure of the categories and the facts of the situation, arranging the facts to meet the criteria of the structure. Further, in the process of trying to describe the logical progression of ideas, he made several errors of logic. The individual thinkers and their ideas become fleshless parts of the structure. Cassirer didn't compare different thinkers, he reconciled them. He found a niche for everyone he considered. Rousseau was a "true son of the Enlightenment" even in his attack on the "Enlightenment." Herder, with his innovations in historical thought, was also seen as part of the unity of the "philosophy of the Enlightenment":

And yet, much as he outgrows the intellectual world of the Enlightenment, Herder's break with his age was not abrupt. His progress and ascent were possible only by following the trails blazed by the Enlightenment. This age forged the weapons with which it was finaliy defeated; with its own

$$
\text { 97Price, pp. 108-109. }
$$


clarity and consistency it established the permises on which Herder based his inference. The conquest of the Enlightenment is therefore a genulne self-conquest. It is one of those defeats which really denote a victory, and Herder's achievement is in fact one of the greatest intellectual triumphs of the philosophy of the Enlightenient. 98

The history of individual thinkers becomes the history of abstractions, analyzed in terms of their relationship to the structure. The ponderous "mind of the Enlightenment," like other categories Cassirer used, keeps reappearing as the supreme arbiter.

Quentin Skinner, in his essay "Meaning and Understanding in the History of Ideas," identifies several fallacies of logic applicable to Cassirex's paradigm, and these can be added to the above criticisms.99 Again, Cassirer's stated intent will be ignored, and the history of the Renaissance or the history of the Enlightenment will be taken as the history of individual works. - Skinner is concerned with looking at the problem of procedure in arriving at an understanding of a work. His analysis of the "school" that concentrates on the text Itself in doing this includes several useful criticisms. Tracing the historical development of a doctrine, Skinnex says, leads to several logical absurdities. First of all, to do so is to assume that there is an "Ideal type" of the given doctrine and that it is immanent in history, even if it is not stated completely by an individual thinker. Most of Cassirex's "logico-historical," "ideal type" categortes are subject. to this criticism. Cassirer wrote about individual works as if they

98 The Philosophy of the Enlightenment, p. 233.

${ }^{99}$ Quentin Skinner, "Meaning and Understanding in the History of Ideas," History and Theory, vol. 9 (1969), pp. 3-53. 
were organic entities, immanent in the seedbed of history, and in the process of approaching the "ideal type," the category itself.

This view of history also leads to statements of "anticipation," .

Skinner argues.- Cassirer was continually guilty of this error, of

seeing the ideas of one thinker "anticipating" those of a later one.

When discussing Shaftesbury, for example, Cassirer contended that

"Shafteşbury thus created for the first time a firm philosophical

center for the future development of genius."100 An even better ex-

ample comes with Cassirer's explanation of the consumation of Pico

della Mirandola's philosophy in later centurles:

For the influence of Pico's philosophy was great and manysided, and extended to almost every realm of intellectual 1ife. The great theme announced in his oration "De hominis dignitate" resounded thereafter in the most diverse variations-in a gradually stronger and stronger crescendo. We hear it in the religious conflicts of the age of the Reformation, we hear it in the new philosophy of nature, and we shall finally hear it-though in altered form-in the modern rebirth of philosophical idealism, in Descartes and Leibniz. The aesthetics and the theory of axt of the following centuries likewise drew upon Pico and took from him many of the basic problems and themes. . The occulta concatenatio' of his own basic ideas and of his seemingly incompatible theses Pico was hardly able to make clear even to himself-much less to make accessible to his contemporaries. Only posterity, only the further philosophical development of the problems, could bring it like buried treasure to light. 101

Pico not only "anticipated" later thinkers, his ideas found fruition only in those thinkers. Cassirer's belief that later intexpreters of an individual's doctrine can understand the doctrine better

100 The Philosophy of the Enlightenment, p. 318.

101 Ernst Cassirer, "Giovanni Pico della Mirandola," Journal of the History of Ideas, vol. 3 (1942), p. 345. 
than that individual himself and his method of seeing the individual in terms of the "spirit" of the epoch fall into a related fallacy, the fallacy of prolepsis. He committed the error of giving each idea, doctrine, or "work" the shape of an organic entity that, In its historical function, approaches an immanent "ideal type." Each "work" Is a seed-germ, growing to fruition only in the systems of later thinkers. Each "work" has to await the future to find its full meaning. Cassirer comitted another fallacy identified by Skinner, the fallacy of finding "coherence" when it is not really there. He attempted to find the "core" of the philosophy of certain individuals In its relation to the group or age being discussed. His interpretation of Rousseau is the best example of his "rage for coherence." Rousseau's diverse influences on later thinkers is of no consequence if attention is directed only to a delineation of his "fundamental thought." Further, the assumption that each oeuvre has a "core" and is a systematic unity is a redundant error in Cassirer's writings. The only unity the oeuvre embodies is one of discourse or explanation on the part of the investigator. The oeuvre is a "reflexive category," a "principle of classification," used by the historian for the purposes of explanation and, as such, does not describe a historical reality. 102 Cassirer collected the "facts" of Individual doctrines,

102 Michel Foucault, The Archaeology of Knowledge, trans. A. M. Sheridan Smith (New York: Pantheon, 1972), p. 22. Foucault is concerned here with dispelling the idea that the collected works of any particular thinker comprise a unity... The concept of oeuvre, he argues, is a reflexive category of the investigator's discourse and must be analyzed as such; that it constitutes an intrinsic and self-evident unity is simply a delusion. 
of the ideas expounded by groups of thinkers, and the "spirit" of epochs into structural unities that become abstractions of the inftial material.

Another error Cassirer made is seen in his assumption that a delineation of the "function" of an idea will give the meaning of the idea. To do this, Skinner points out, "We cannot write about the Idea itself, the sentence, but only about the statements made about the sentence." 103 Cassirer's "rage for coherence" makes him suspect of abstraction again. Even "function" was contingent on the unity of the scheme.

Cassirer's use of "Facts" was also affected by his deference to structure, to the coherent scheme. Again, the individual "Eacts" were important only in terms of the greater category. Cassirer believed historical research to begin with the analysis of "monuments." Through this analysis, the "facts in the monument" are discerned. The "facts" In each "monument" are dependent on the relationship between "monuments." And as that relationship changes, the meaning of the "facts" changes, accordingly. Cassirer made certain assumptions about these relationships. He assumed, for example, that all of an individual's writings, his oeuvre, constiture an organic and coherent whole. In some cases, most notably with the Cambridge Platonists, he assumed that the "monuments" within a school of thinkers form a coherent whole. Therefore, the "facts" and the meaning of the "facts" form a coherent ${ }^{103}$ Skinner, p. 37 
unity. Again, his "rage for coherence" leads him to defer to structure at the expense of the particulars of the analysis.

Moreover, the "monuments" Cassirer used revolved around the thinking of individuals. He had little concept of causality. Economical, political, and psychological motivations are disregarded. He did make a palld attempt to fill in a few of the details of Rousseau's IIfe, but these were obvifously of small importance in the light of. Rousseau's intellectual documents. 104 Cassirer assumed a cognitive comerstone for all intellectual constructs. The cognitive faculty is universal, he believed, and intellectual "monuments" represent the workings of that faculty. They are symbolic axtifices, created by the symbolizing mind, isolated from their political, economical, social and psychological environments. 105

Cassirer gave the reader a topology of conceptual patterns. within a rough chronological framework. And even this framework was carelessly constructed. He has been criticized for making blatant chronological errors. 106 And chronology was of little or no importance when he discussed how one thinker "anticipated" a later one, or how an earlier doctrine found fulfillment in a later one. He noted

${ }^{104}$ Ernst Cassirer, The Question of Jean-Jacques Rousseau, trans. Peter Gay (Bloomington, Indiana: Indiana University Press, 1967), pp. 7-32.

${ }^{105} \mathrm{Cf}$. Herbert Dieckmann, "An Interpretation of the Eighteenth Century," Modern Language Quarterly, vo1. 15 (1954), p. 309; John Herman Randall, Jr., "Cassirer's Theory of History as Illustrated in His Treatment of Renaissance Thought," in The Philosaphy of Ernst Cassirer, ed. Paul Schilpp, pp. 703-4. "So far as Cassirer's analysis goes," Randall comments, "thought might as well be operating in a vacuum". ${ }^{106}$ Dieckmann, pp. 299, 303. 
similarities between the ideas of different thinkers regardless of their places in time or space. In a characteristic example, Rousseau was compared to Leibniz:

Thus Rousseau returned, in a thoroughly individual way, from Condillac to Leibniz. Historically, this turning point is all the more remarkable since we can nowhere observe any direct influence that Leibniz's fundamental thought might have exercised on Rousseau. The epistemology which Rousseau wove into the 'Professions de foi du vicaire savoyard' frequently reminds us line by line of Leibniz's Noveaux Essais--but it is known that this work was published only in the year 1765, From the manuscript in the library in Hanover, three years after the appearance of Emile.

For Cassirer's purposes, the Noveaux Essals inght as well have been published much earlier, at least early enough that Rousseau could have copled it "line by line."

Despite the criticism of Casstrer's penchant for structure and affinity for schemata, he has had a profound influence on the general. community of historians. His work in many areas was unique and he did considerable original research. 108 He has had some influence on subsequent historians, especially with some of the specifics of his data. 109 Even the abundance of criticisms of his works attests to the seriousness with which he has been viewed as a histortan.

107 The Question of Jean-Jacques Rousseau, pp. 112-113.

${ }^{108}$ Diekmann couples praise with criticism in his review of The Philosophy of the Enlightenment; Peter Gay, in the introduction to his translation of The Question of Jean-Jacques Rousseau, sees the essay as. "an aesthetic as well as intellectual achievement of the irst order," one of great significance in the history of interpretations of Rousseau. (p. 24, see pp. 21-30.)

${ }^{109}$ See the notes to Peter Gay's The Enlightenment: An Interpretatlon (New York: Alfred A. Knopf, 1969), vol. 2. 
But Cassirer used a paradigm charged with possibilities for fallacy. He accepted the idealist view that "mind" and "matter" are identical, that "mind" operates according to the rules of logic, and that logic can be applied to the history of thought. 110 He used the . analytic-synthetic idealist approach, the breakdown and recreation of a body of data. The history of thought--the history of the "mind"moved. from an analytical period to an organic one in a never ending process, Cassirer believed. And at each juncture, at: each organic stage, there was a transitional figure to bring everything together again: Nicholas of Cusa, Descartes, Leibniz, Kant, and others. Cassirer, in his response to the "crisis" situation, to the plethora of fragmented theories of man, to an analytical period in European thought, saw himself as a new transitional figure. His paradigm was a response to a "crisis" In Kuhn's sense of the word. But at. the same time, within the framework of Cassirer's scheme, it was intended to provide the new synthesis in the development of the "modern mind." Cassirer's synthetic paradigm fulfills the criteria Hollinger names for "successful" works in the field.111 And he must be lauded for explaining his methodological position and consistently abiding by it. But if the basic tenets of idealist philosophy are not accepted, his entire model fails as a viable paradigm for historlcal research and writing. Implicit in the criticisms of Price, Skinner, Foucault, and others is the recognition of the absurdity of these tenets. The pursuit $80-111$.

110 On the idealist approach to history, see coates and White, pp.

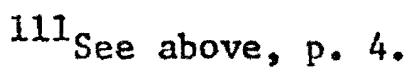


of the history of the "mind," of the "knowledge of knowledge," can only lead to historical absurdities. 


\section{BIBLIOGRAPHY}

Cassirer; Ernst.. An Essay on Man. New York: Bantam, 1970 .

- "Ficino's Place in Intellectual History." Journal of the History of Ideas, VI (1945), 492-520

"Galileo: A New Science and a New Spirit." American Scholar, XII. (1942), 5-19.

- "Galileo!'s Platonism." Studies and Essays in the History

of Science and Learning. Edited by M. F. Ashley Montagu.

New York: Henry .Schuman, 277-298.

- "Giovanni Pico della Mirandola." Journal of the History of

Ideas, III (1942), 123-144.

- "Herman Cohen." Social Research, X (1943), 219-232.

- The Individual and the Cosmos in Renaissance Philosophy.

Translated by Mario Domandi. New York: Barnes and Noble, 1963.

- The Logic of the Humanities. Translated by Clarence Smith

Howe. New Haven: Yale University Press, 1961.

- "Naturalistische und Humantische Begrundung der Kulturphilosophie." Der Bogen, II (1947), 11-26.

"Newton and Leibniz." The Philosophical Review, III (1943), 366-91.

- The Philosophy of the Enlightenment. Translated by Fritz

C. A. Koelln and James P. Pettegrove. Boston: Beacon Press, 1965.

- The Philosophy of Symbolic Forms: Language. Translated by Ralph Manheim. New Haven: Yale University Press, 1953.

- The Philosophy of Symbolic Forms: Mythical Thought. Translated by Ralph Manheim. New Haven: Yale University Press, 1955.

- The Philosophy of Symbolic Eorms: The Phenomenology of Knowledge. Translated by Ralph Manheim. New Haven: Yale University Press, 1957.

- "The Place of Vesalius in the Culture of the Renaissance." Yale Journal of Biology and Medicine, XVI (1943), 109-120. 
- The Platonic Renaissance in England. Translated by James P. Pettegrove. Austin: University of Texas Press, 1953.

- The Problem of Knowledge: Philosophy, Science, and History Since Hegel. Translated by Whlliam H. Woglum and Charies. W. Hendel. New Haven: Yale University Press, 1970.

- The Question of Jean-Jacques Rousseau. "Translated with an Introduction by Peter Gay. Bloomington, Indiana: Indiana University Press, 1967.

- Rousseau, Kant, Goethe. Translated by James Gutmann, Paul Oskar Kristeller, and John Herman Randall, Jr. Princeton: Princeton University Press, 1947.

- "Some Remarks on the Question of the Originality of the Renaissance." Journal of the History of Ideas, IV (1943), 49-56.

- Substance and Function. Translated by William C. Swabey and Marie C. Swabey. Chicago: Open Court, 1943.

Coates, Willson H., and White, Hayden V. The Ordeal of Liberal Humanism. New York: McGraw-Hi11, $1 \overline{970}$, Vol. 2 .

Dieckmann, Herbert. "An Interpretation of the Eighteenth Century." Modern Language Quarterly, XV (1954), 295-311.

Foucault, Michel. The Archaeology of Knowledge. Translated by A. M. Sheridan Smith. New York: Pantheon, 1972.

Gay, Peter. The Enlightenment: An Incerpretation. New York: Alfred A. Knopf, 1969, Vol. 2 .

- "The Social History of Ideas: Ernst Cassirer and After." The Critical Spirit. Edited by Kurt H. Wolff and Barrington Moore, Jr. Boston: Beacon Press, 1955.

Gawronsky, Dimitry. "Ernst Cassirer: His Life and His Work." The Philosophy of Ernst Cassirer. Edited by Paul Schilpp. Menasha, Wisconsin: George Banta, 1949.

Hamburg, Carl H. Symbol and Reality: Studies in the Philosophy of Ernst Cassirer. The Hague: Martinus Nifhoff, 1956.

Hodges, H. A. The Philosophy of Wilhelm Dilthey. London: Routledge and Kegan Paul, 1952 . 
Holborn, Hajo. "Wilhelm Dilthey and Critique of Historical Reason." European Intellectual History Since Darwin and Marx. Edited by W. Warren Wagar. New York: Harper and Row, 1966.

Howlinger, David A. "T. S. Kuhn's Theory of Science and Its Implications for History." American Historical Review, 78 (1973), 370-93.

Hughes, H. Stuart. Consciousness and Society. New York: Vintage, 1958.

Iggers, Georg G. The German Conception of History. Middletown, Conn.: Wesselyan University Press, 1968.

Itzkoff, Seymour W. Ernst Cassirer: Scientific Knowledge and the Concept of Man. Notre Dame: University of Notre Dame Press, 1971

Jenkins, Irede11. "Logical Positivism, Critical Idealism, and the Concept of Man." Journal of Philosophy, 47 (1950), 677-695.

Klibansky, R. and Solmitz, W. "Bibliography of Ernst Cassirer's Writings." Philosophy and History: Essays Presented to Ernst Cassirer. Editad by R. KIIBansky and H.J. Paton. New York: Haxper and Row, 1963.

Kristeller, Paul Oskar. "The History of Philosophy and the History of Ideas." Journal of the History of Philosophy, VII (1964) $6-21$.

Kuhn, Helmut. "Review: An Essay on Man." Journal of Philosophy, 42 (1945), 384-388.

Kuhn, T. S. "The Relations Between History and the History of Science." Historical Studies Today. Edited by Felix Gilbert and Stephen R. Graubard. New York: W. W. Norton and Co., 1972. - The Structure of Scientific Revolutions. Chicago: University of Crifcago Press, 1970.

Makkreel, Rodolf A. "Wilhelm Dilthey and the Neo-Kantians: The Distinction of the Geisteswissenschaften and the Kulturwissenschaften." Journal of the History of Philosophy, VII. (1969), $423-440$.

Masur, Gerhard. Prophets of Yesterday: Studies in European Culture; 1890-1914. New York: Macmillan, 1961. 
Mosse, George I. The Culture of Western Europe: The Nineteenth and Twentieth Centuries. New York: Rand McNally and Co., 1961 .

Northrop, F. S. C. "Obituary: Ernst Cassirer." The Philosophical Review, LV (1946), 450-51.

Price, Kingsley. "Ernst Cassirer and the Enlightenment." Journal of the History of Ideas, XVIII (1957), 101-112.

Randa11, John Herman, Jr. "Cassirer"s Theory of History as Illustrated in His Treatment of Renaissance Thought." The Philosophy of Ernst Cassirer. Edited by Paul Schilpp. Menasha, Wisconsin: George Banta, 1949 .

Skinner, Quentin. "Meaning and Understanding in the History of Ideas." Iistory and Theory, VIII (1969), 3-53.

Slochower, Harry. "Ernst Cassirer's Functional Approach to Art and Literature." The Philosophy of Ernst Cassirer. Edited by Paul Schilpp. Menasha, Wisconsin: George Banta, 1949.

Solmitz, Walter M. "Cassirer on Galileo: An Example of Cassirer's Way of Thought." The Philosophy of Ernst Cassirer. Edited by Paul Schilpp. Menasha, Wisconsin: George: Banta, 1949.

Stern, Fritz. The Politics of Cultural Despair. New York: Doubleday and Co., 1961 .

Verene, Donald P. "Ernst Cassirer: A Bibliography." Bulletin of Bibliography, XXIV (1964), 103-106.

- "Kant, Hegel, and Cassirer: The Origins of the Philosophy of Symbolic Forms." Journal of the History of Ideas, XXX (1969), $32-46$.

Werkmeister, William H. "Cassirer's Advance Beyond Neo-Kantianism." The Philosophy of Ernst Cassirer. Edited by Paul Schilpp. Menasha, Wisconsin: George Banta, 1949.

Wienex, Phillp P. "Some Problems and Methods in the History of Ideas." Journal of the History of Ideas, XXII (1964), 531-548.

Wollner, Craig. "The Attack on Bourgeois Society: An Introduction to Cultural Despair in the Late Nineteenth and Twentieth Century European Thought." Unpublished M. A. thesis, Portland State University, 1969. 